\title{
ADAPTATION “INSTITUTE OF RADIO ELECTRONICS” BUILDING IN KHARKIV FOR MODERN USING
}

\author{
Shvydenko O., PhD of Architecture, Associate Professor of Department of Reconstruction, \\ restoration of architectural objects \\ Kharkiv National University of Civil Engineering and Architecture, \\ e-mail: olgadocomomo@gmail.com,ORCID:0000-0002-1645-2760
}

\begin{abstract}
Adaptation to modern requirements of buildings, which have got a status of architectural landmarks, is always a compromise between the preservation of authentic elements and bringing the building into line with current standards. In the Building of the Institute of Radio Electronics, the architectural landmark of Kharkiv region, it was necessary to build an elevator to provide barrier-free access to the premises.
\end{abstract}

The goal of this research is to find the best place for a new elevator, where meddling into the building's body from one side will make minimum damage for its structure and interior design and from another side can be most convenient for users.

To solve this problem, it was necessary to collect materials about "Institute of radio electronics" building: conduct bibliographic surveys and search materials in different archives. Historical documents, photos, sketches and historical drawings and field research materials about this building must be put together.

Analysis of the collected materials showed that building was designed in the second part of 1930 for new Kharkov Civil Engineering Institute (KhCEI), which was found in April 1930.

In 1930 the place for the building structure was chosen. A KhCEI building architectural competition took place in 1930. The authors of the winning project were Yakiv Steinberg, Rosaliya Fridman. For the KhCEI building J. Steinberg suggested to make experimental constructivist complex. The architect paid special attention to the functioning of the building. Taking into attention that the formation of the department structure of the institute continued until 1932, the architects had only approximate characteristics of the functioning of the house.

The building had a long distributor block to which other blocks, intended for separate specializations, were adjoined at right angles. The stairways or ramps were in the corridors of the distributor block as well as in the opposite edges of the transverse blocks. The ground floors and second floors had corridors, which distributed students to the necessary premises. The first floor and partly the ground floor were intended for laboratories. The second floor, which had a corridor system, was divided into small rooms for group classes, and the third floor contained large halls for drawing classes had free planning (later became enfilades). Near the stairs there were also the servicing premises combined in one block - toilets, tool rooms and archives, professors' offices with small subdepartment libraries.

Only one half of this project was finished in 1933. The complex was damaged during the II World war. In August 1943, the destroyed building was handed to Kharkiv Mining Engineering Institute (KhMEI).

In 1944-1945 Dmitry Torubarov developed the project of reconstruction of this complex. His solution preserved Steinberg's idea, but added new parts to it. Torubarov changed the outer view of the complex, because the environment around it had been modified.

In 1930 Steinberg worked with an empty area, where were only the main road and the ravine. He made a composition, which was supposed to look from the view point between the main road and the ravine best of all. In 1946 Torubarov worked in the new town area, where the ravine created an empty space in front of the composition. The corner between the main road (that became a significant avenue later) and the ravine wasn't so important. Torubarov moved the center of the composition to the center of facade facing to the ravine. 
In 1947 the structure of the institute was totally changed. There were many reasons for which a new building reconstruction project was made instead of Torubarov's project.

In 1947 the project of reconstruction for KhMI was handled by Noy Podgorny. The project that was made by Podgorny had more large-scale and monumental view than the previous projects. In this project two educational blocks and several dormitory blocks were added. The project task which issued by the chief architect of the city stated that the new KhMI complex had to be a part of an ensemble.

Podgorny turned the complex into a quarter building, leaving only 2 open inner courtyards in the center of each main facade. He enlarged the scale of the building. The appearance of the building was completely changed - the building received facades in the Stalin's Art Deco style.

For the Stalinist Art Deco style, traffic flows in the buildings not were too important. Inside the building, the premises were divided into front rooms - vestibules, staircases, halls and back office rooms - the actual working rooms. Podgorny couldn't change the working rooms too much, but he created the new front rooms.

Drawings were completed and agreed by 1950. The educational buildings were commissioned in 1968. In 1966 the institute was transformed into the Kharkov Institute of Radio Electronics. In 1980 the buildings of the Institute of radio electronics, which were built and rebuilt in the style of the Stalin's Art Deco received the status of architectural landmarks.

Modern traffic flows in the building were considered and it was determined that the best place for the elevator is the staircase in distributor building.

The staircase hall retained the features of the early 1930s and also should preserve some authentic elements as much as possible. However, a comparative analysis with other monuments of this period showed that the design of the stairs proposed by Steinberg had variations, one of them had an elevator inside it.

In such stairwells, elevators were enclosed in a transparent sheath to show the machine's action. In the 1930s, the transparent walls of the elevator shaft were made of wire mesh, but in order to emphasize the introduction of a new non-genuine element in the staircase composition, it was proposed to assemble the elevator in a transparent glass shaft.

Key words: adaptation, landmarks, modern monument, constructivism, stalin's Art Deco style, Yakiv Steinberg, Dmitry Torubarov, Noy Podgorny.

\section{ПРИСТОСУВАННЯ ПІД СУЧАСНЕ ВИКОРИСТАННЯ ПАМ'ЯТКИ АРХІТЕКТУРИ ТА МІСТОБУДУВАННЯ ІНСТИТУТУ РАДІОЕЛЕКТРОНІКИ В ХАРКОВІ}

Швиденко О. О., к. арх., доцент кафедри реконструкції, реставрації архітектурних об'єктів Харківський національний університет будівництва та архітектури e-mail: olgadocomomo@gmail.com,ORCID:0000-0002-1645-2760

Анотація. Пристосування до сучасних вимог будівель, що є пам'ятками архітектури, завжди стає компромісом між збереженням автентичних елементів і приведенням будівлі у відповідність до чинних норм. У будівлю інституту радіоелектроніки, пам'ятку архітектури місцевого значення, необхідно було вбудувати ліфт, щоб забезпечити безбар'єрний доступ в приміщення.

Щоб знайти місце для ліфта, були зібрані й структуровані в хронологічному порядку різні типи джерел, які дозволили відновити будівельну історію пам'ятки. Було виявлено, що будівля була побудована в 1930-1932 роках за конструктивістським проектом Я. Штейнберга. Вона була реконструйована частково за проектом Д. Торубарова (1944-1947 рр.), а потім за проектом Н. Підгірного (1947-1968рр.). В результаті будинок одержав характерний для сталінського арт-деко вид. 
На основі цих матеріалів була виявлена історична, містобудівна та художня цінність пам'ятки, що дозволило знайти рішення найбільш безболісного включення в будівлю нового елемента.

Ключові слова: адаптація, пам'ятка архітектури, пам'ятка ХХ століття, конструктивізм, сталінське ар-деко, Я. А. Штейнберг, Д. Р. Торубаров, Н. М. Підгірний.

\section{ПРИСПОСОБЛЕНИЕ ПОД СОВРЕМЕННОЕ ИСПОЛЬЗОВАНИЕ ПАМЯТНИКА АРХИТЕКТУРЫ И ГРАДОСТРОИТЕЛЬСТВА ИНСТИТУТА РАДИОЭЛЕКТРОНИКИ В ХАРЬКОВЕ}

Швыденко О. А., к. арх, доцент кафедры реконструкции, реставрации архитектурных объектов

Харьковский начиональньй университет строительства и архитектурь e-mail: olgadocomomo@gmail.com,ORCID:0000-0002-1645-2760

Аннотация. Приспособление к современным требованиям зданий, являющихся памятниками архитектуры, всегда компромисс между сохранением подлинных элементов и приведением здания в соответствие действующим нормам. В здание института радиоэлектроники, памятник архитектуры местного значения, необходимо было встроить лифт, чтобы обеспечить безбарьерный доступ в помещения.

Чтобы найти место для лифта, были собраны и структурированы в хронологическом порядке различные типы источников, которые позволили восстановить строительную историю памятника. Было выявлено, что здание было построено в 1930-1932 годах по конструктивистскому проекту Я. Штейнберга. Оно было реконструировано частично по проекту Д. Торубарова (1944-1947 гг.), а затем по проекту Н. Подгорного (1947-1968 гг.). В результате здание получило характерный для сталинского арт-деко вид.

На основе этих материалов была выявлена историческая, градостроительная и художественная ценность памятника, что позволило найти решение наиболее безболезненного включения в здание нового элемента.

Ключевые слова: адаптация, памятник архитектуры, памятник архитектуры XX столетия, конструктивизм, сталинское арт-деко, Я. А. Штейнберг, Д. Р. Торубаров, Н. М. Подгорный.

Introduction. In the "Institute of radio electronics" building in Kharkiv now locates Kharkiv National University of Radio Electronics (NURE). In this University are trained the specialist for IT area. People with disabilities, first of all young people, who use disabled carriage, are very interesting in getting education in this sphere. For this reason university administration in 2019 decided to adopt the main university building for such students. One of the obligatory changes was equipping the building with an elevator.

"Institute of radio electronics" building is found in the List of architectural landmarks of Kharkiv region. Any encroachment into the building's body has to be based on scientific research, which aims to preservation of this monument.

Analysis of recent research or publications. The methodology of working with the monument is set out in the main international charters for the protection of cultural heritage [1-2]. The basics of the monuments adaptation are recorded in the monograph "Restoration of architectural monuments" [3]. As for the concrete monument, the building of the Institute of radio electronics is poorly represented in publications. Most of the information relates to the history and activities of scientific institutions located in it [4-5]. The detailed architectural description of the object is given only in the article by J. Steiberg [6]. The building is also mentioned in the guidebook of the most interesting architectural objects of Kharkov [7, p. 91] and in a short local history review devoted to the buildings of higher educational institutions in Kharkov [8]. 
The goal of this research is to find the best place for a new elevator, where meddling into the building's body from one side will make minimum damage for its structure and interior design and from another side can be most convenient for users.

Research methodology. To solve the problem, it is necessary to collect materials about "Institute of radio electronics" building: conduct bibliographic surveys and search materials in different archives. Historical documents, photos, sketches and historical drawings and field research materials about this building must be put together. These materials must be structured in chronological order to get a complete view of the changes that occurred with the building. On this basis, the historical and cultural value of the object, its urban planning and artistic value will be evaluated. That will allow us to identify the most valuable parts of the building and identify the place where the installation of the elevator would be caused with the least damage to the monument.

Research results. Analysis of the collected materials in the chronological order showed that building was designed in the second part of 1930 for new technical institute of building, which was found in April 1930. New institute was established from the building department of the Kharkiv Polytechnic Institute (KhPI) and from the architectural department of the Kharkiv Artistic Institute. The last one was the famous architectural school in 1920th.

The structure of the new institute, which was named Kharkov Civil Engineering Institute (KhCEI), took shape only in the spring of 1931. There were 4 specialization (departments) practical, sanitary engineering, structural and design - and 14 subdepartments. The new institute was equal to a military academy, where not only civil engineers, but also commanders for sapper troops were trained for. Many efforts were focused on physical trainings and political work. In 1934 in KhCEI department of geodetic engineering was established from the Kharkiv Geodetic Institute and the Research Institute of Geodesy and Cartography [5].

After stabilization of this department structure of KhCEI, in 1934 research work was started up. The structure of labs that had relation to the research work was formed only in the second part of 1930th. There were only 10 labs in KhCEI in 1934, but 1941 KhCEI already had 42 labs, which area was $2276 \mathrm{~m}^{2}$.

In 1930 when decision of the foundation of the new institute was made, the place for the building structure was chosen. It was near the boundary of Kharkiv, on Shatilovka region. This area had a good connection with the new downtown, which was under construction that time.

A KhCEI building architectural competition took place in summer-autumn of 1930 . We don't have a lot of information about the competition; we only know the names of winners and winner project description. The authors of the winning project were Yakiv Steinberg, Rosaliya Fridman, for participation A. Zaslavsky.

Yakiv Steinberg was a bright young architect, who had designed the Club of Builders, some interiors in Derzhprom, made reconstruction for building of Central committee of Ukrainian Communist Party in the new downtown, actively participated in architectural competitions. He was active member of Ukrainian society of modern architects, took part in different cultural activities, and made many publications in different magazines. He also was a teacher in the Kharkiv Artistic Institute, conducted research in the area of architectural morphology and composition.

Rosaliya Fridman was one of the first female architects in Kharkiv. In1926 she graduated the Kharkiv Technological Institute (later KhPI) and started work with Yakiv Steinberg in the Industroy. She was also a teacher in the Kharkiv Artistic Institute.

The KhCEI building project was published by J. Steinberg in the "Construction" magazine [6], which was published in November 1930. In 1930 there were started a reform of the research institutes in USSR, the number of which increased significantly. Steinberg thought his experience would be useful for other architects, who might face a similar task. 
For the KhCEI building J. Steinberg suggested to make experimental constructivist complex. The architect paid special attention to the functioning of the building. Taking into attention that the formation of the department structure of the institute continued until 1932, the architects had only approximate characteristics of the functioning of the house. Therefore, the complex was planned in such a way that future departments and subdepartments would be able to operate separately, but would be conveniently connected to the premises common to all specializations.

The building had a long distributor block (now building "D") to which other blocks, intended for separate specializations, were adjoined at right angles. At the point of intersection of the blocks there were halls, which, due to the displacement of the central axes of the perpendicular blocks, received natural light. The stairways or ramps were in the corridors of the block D as well as in the opposite edges of the transverse blocks. The ground floors and second floors had corridors, which distributed students to the necessary premises. The first floor and partly the ground floor were intended for laboratories. The second floor, which had a corridor system, was divided into small rooms for group classes, and the third floor contained large halls for drawing classes that had free planning (later became enfilades). Near the stairs there were also the servicing premises combined in one block - toilets, tool rooms and archives, professors' offices with small subdepartment libraries.

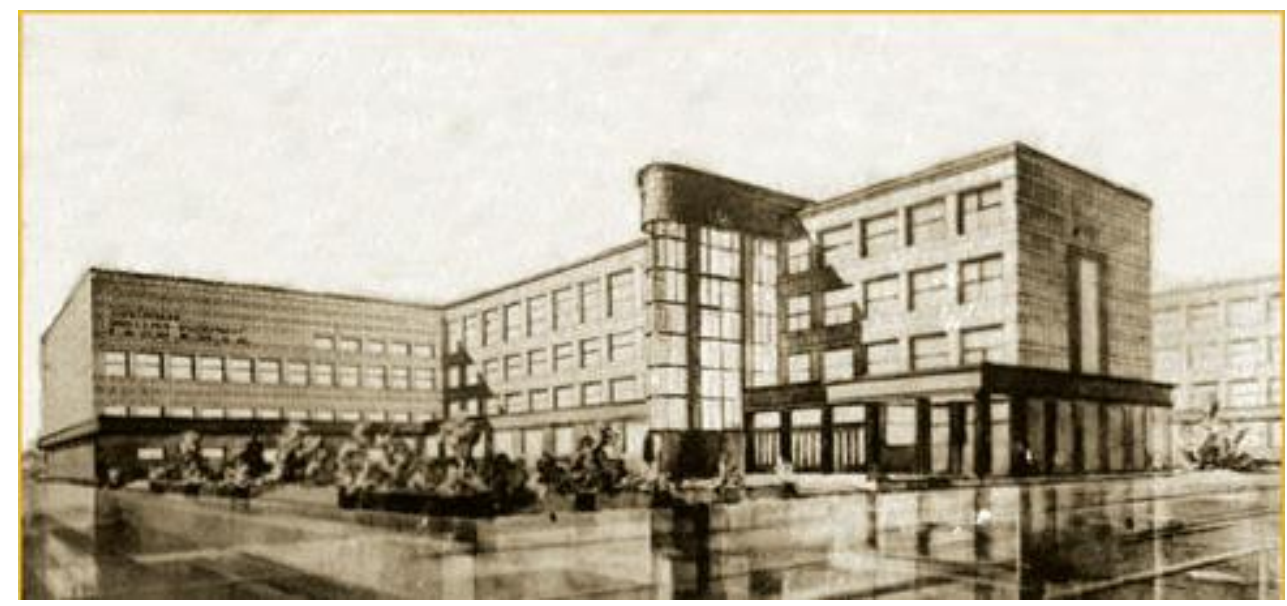

Fig. 1. The KhCEI building. Arch. Yakiv Steinberg, Rosaliya Fridman, for participation A. Zaslavsky. Picture from the Museum of the Kharkov National University of Radio Electronics. 1930s

At the ends of the perpendicular blocks there were large amphitheater classrooms. The library and the large hall were situated in the inner courtyards.

Only one half of this project was implemented - were built the 5 blocks, adjoined to the main road. This part of the complex was finished in 1933. The second part of the complex carried out only in 1970th, using another project.

In 1941 the military hospital was accommodated in the KhCEI building. The complex was damaged during the war. In August 1943, the destroyed building were handed over to KhCEI, which belonged to the People's Commissariat of the coal industry. In September 1944 this institute was reorganized in the Kharkiv Mining Engineering Institute (KhMEI).

From the description of the educational process in the KhMEI we know, that in 1944 were formed teams of teachers and students for restoration works. In 1944-1945 the head of the department of architectural design and composition of KhMEI, associate professor Dmitry Torubarov developed the project of reconstruction of this complex. He planned to rebuild all old blocks, build 2 new blocks, close a yard on the side of the ravine with the colonnade, upgrade the block "D" and make the tower above the two new blocks. Torubarov changed the outer view of complex, because the environment around it was modified. 


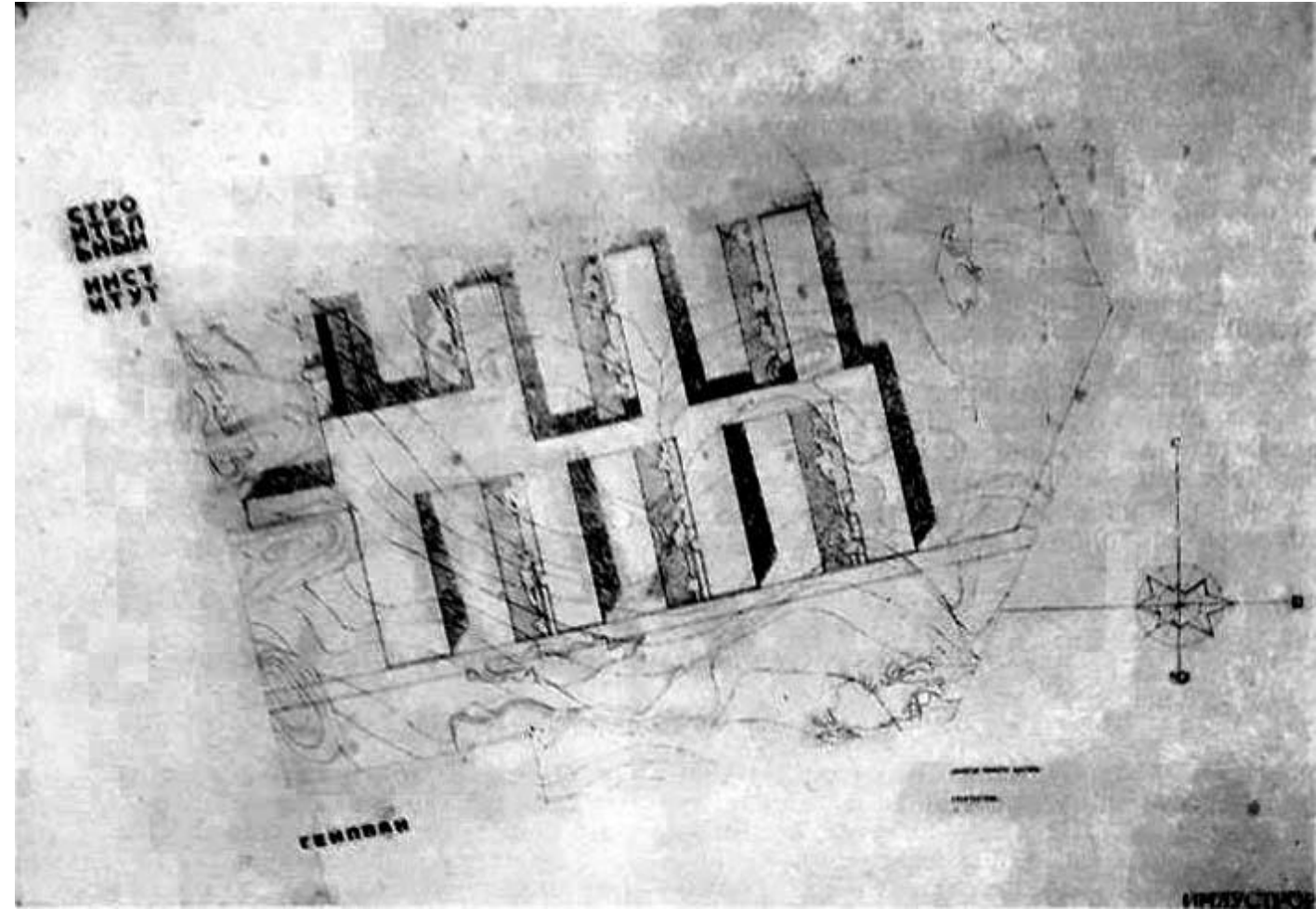

Fig. 2. Masterplan of the KhCEI building. Arch. Yakiv Steinberg, Rosaliya Fridman, for participation A. Zaslavsky

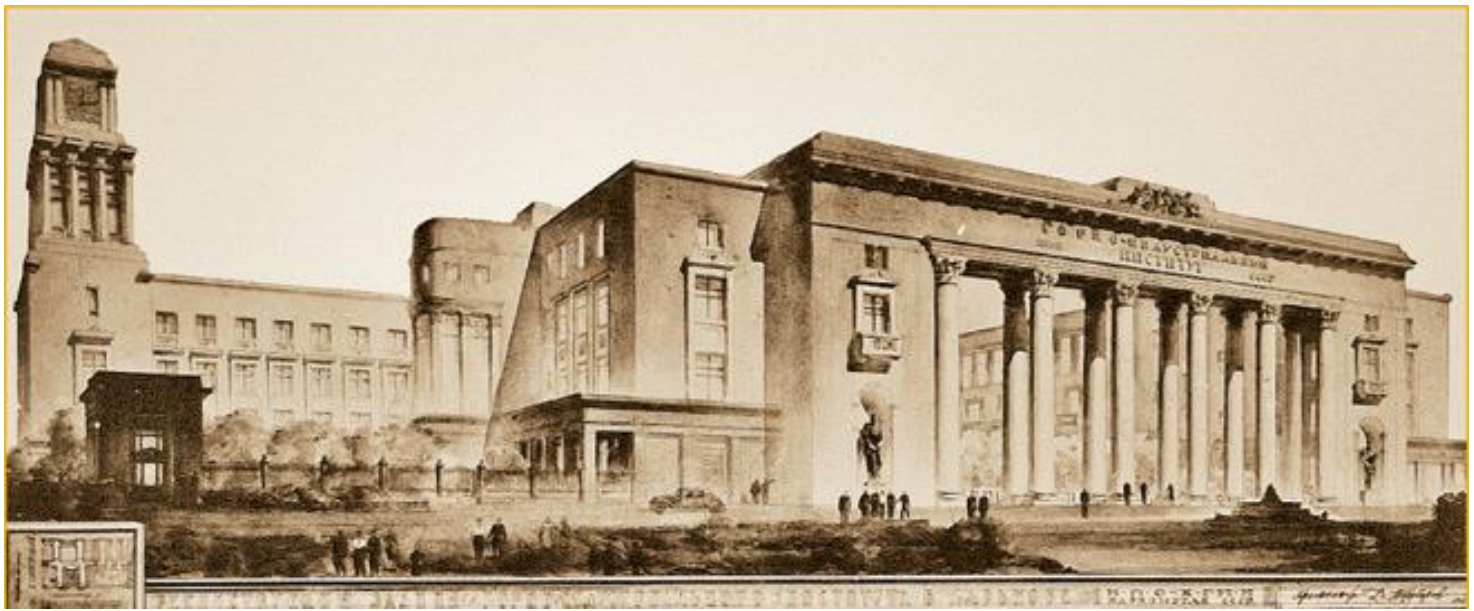

Fig. 3. The KhMEI building. Arch. Dmitry Torubarov. Picture from the Museum of the Kharkov National University of Radio Electronics. Near 1947

In 1930 Steinberg worked with an empty area, where were only the main road and the ravine, which separated the building site from some buildings of downtown. He made a composition, which was supposed to look from the view point between the main road and the ravine best of all. In 1946 Torubarov worked in the new town area, where the ravine created an empty space in front of the composition. The corner between the main road (that became a significant avenue later) and the ravine wasn't so important. Torubarov moved the center of the composition to the center of facade facing to the ravine. His solution preserved Steinberg's idea, but added new parts to it. According to the official version Torubarov's project was not implemented due to missing of costs, but cuntemporary studies show that the reparation and addon to the old buildings was carried out according to his project. 
In 1947 the structure of the institute was changed again. All students and teachers who learned and studied civil engineering were moved to other specialized institutes in Kharkov. The institute began to produce only specialists for mines. But in 1950s this allowed to begin the graduation of specialists in the field of automation and telemechanics.

There were many reasons for which a new building reconstruction project was made instead of Torubarov's project. Among them - the new structure of the institute, the moving of Torubarov to a new place of work, new project task issued by the chief architect of the city and the incompliancy of Torubarov's project to the main style of Stalin's art deco.

In 1947 the project of reconstruction for HkMI was handled by Noy Podgorny. He was a head of the subdepartment of architectural design and composition, the head of the architectural group of the research and development department of the research and production department of KhMI. In his project he referred Toruburov as a consultant.

The project that was made by Podgorny had more large-scale and monumental view than the previous projects. In this project two educational blocks and several dormitory blocks were added. The project task which issued by the chief architect of the city A. Kasyanov stated that the new KhMI complex had to be a part of an ensemble. Kasyanov imagined this like an one side of a propylaea which would be welcoming people at the entrance to the new city center. The second part would be the future Giprostal building.

Podgorny turned the complex into a quarter building, leaving only 2 open inner courtyards in the center of each main facade. He enlarged the scale of the building, made it monumental and ceremonial. The appearance of the building was completely changed - the building received facades in the Stalin's Art Deco style. Centers of the facades in the inner courtyards were decorated with porticos with columns, which height equal to a height of the building [7].

But after changes this complex didn't look like dominant in environment. It became an ordinary object that set the huge scale for the surrounding buildings. The tower on the building looked only like accent.

Podgorny did not consider that it is necessary to preserve the basis of the constructivist building, not only because he was not a supporter of constructivist ideas, but also because after changing the orientation of the institute the need for large drawing rooms disappeared. For the Stalinist Art Deco style, traffic flows in the buildings not were too important. Inside the building, the premises were divided into front rooms - vestibules, staircases, halls and back office rooms the actual working rooms.

Apparently, Podgorny couldn't change the working rooms too much, because they had already been repaired according to the project of Torubarov and the teaching process already went in them. Therefore, he limited himself by completing the complex, closing the previously open courtyard at the intersection of the main road and the street in the front of the ravine. In the new educational blocks, a corridor layout was used.

But he created the new front rooms. He completely remade the distant lobby hall in the block "D", making the main entrance there. He created there a grand staircase, a two-light main entrance hall and a grand assembly hall above it.

Podgorny completely rebuilt the old educational block, which overlooked the main road. Now it became a pass-through building, that unit the dormitory blocks and educational blocks. He housed there the university administration, the dining room, and the second main lobby at the entrance from the avenue.

Drawings were completed and agreed by 1950. In 1953-1958 all educational buildings were commissioned except the building with the second main lobby. It was completed in 1968.

In 1962, the Kharkov Mining Institute was reorganized into the Kharkov Institute of Mining Engineering, Automation and Computer Engineering. In 1966 it was transformed into the Kharkov Institute of Radio Electronics. The Kharkov Institute of Radio Electronics twice raised its status: in 1993 it received the status of a technical university, and in 2001 took the status of a national university [4]. 


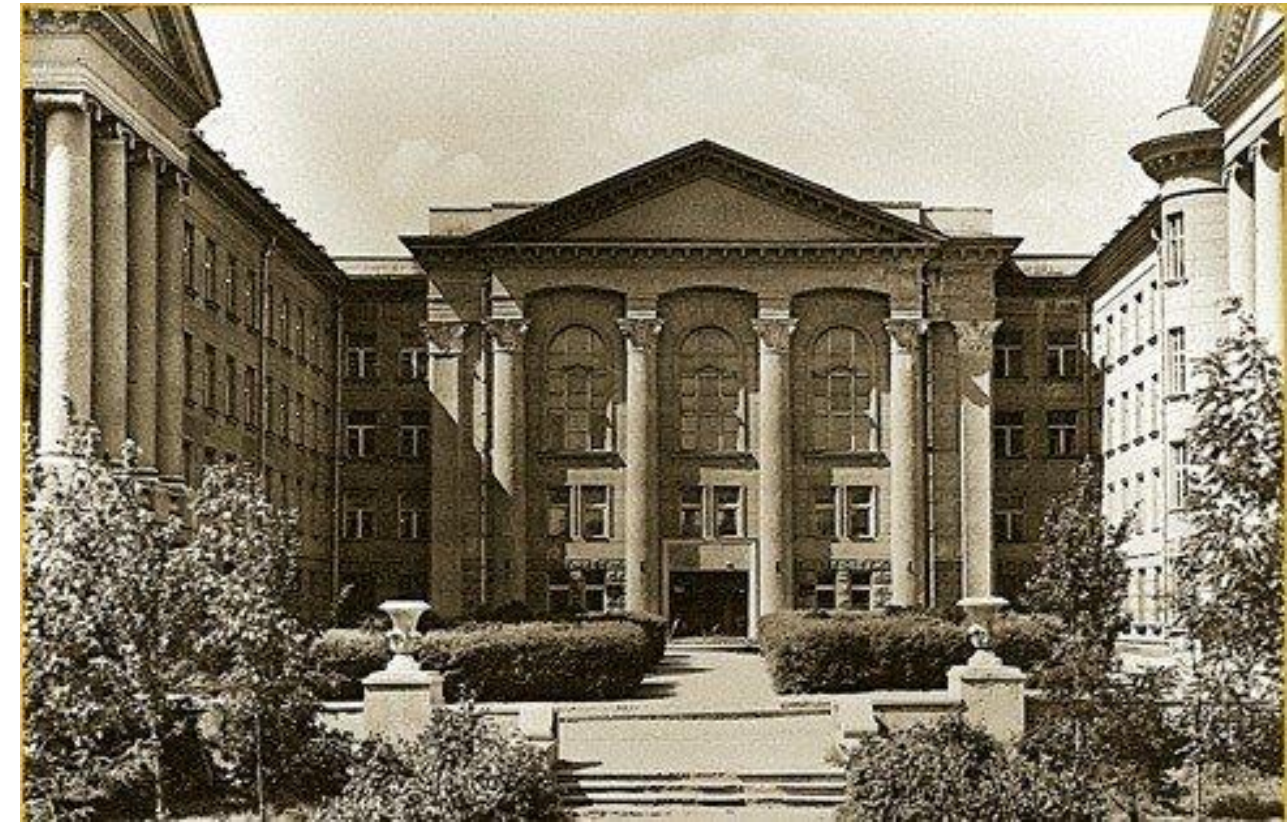

Fig. 4. The KhMI building. Arch. Noy Podgorny. Photo from the Museum of the Kharkov National University of Radio Electronics. Near 1958

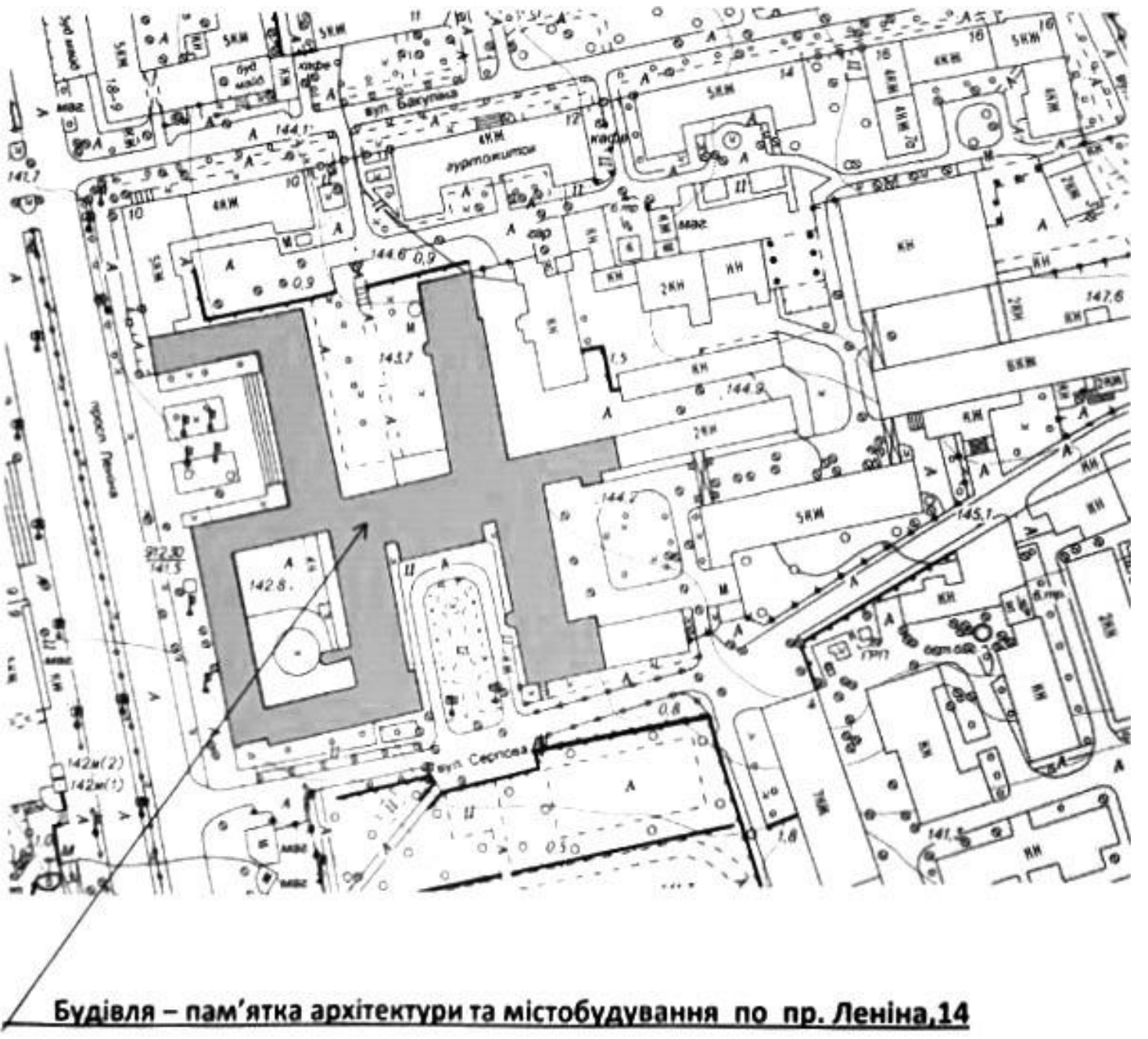

Fig. 5. Site plan of Building of Institute of Radio Electronics. 2012. Drawing from the archive of the Kharkov National University of Radio Electronics 
In 1980 the buildings of the Institute of radio electronics, which were built and rebuilt in the style of the Stalin's Art Deco received the status of architectural landmarks. It was noted that the building was created in the 1930s, and then was rebuilt.

In 2015 new documentation for the monument was made. It was determined that the monument has cultural value because it is characteristic of the architectural direction of the period of the late 1940s - early 1950s and reflects trends of representativeness with the use of elements of classical heritage and is distinguished by a special monumentality.

An additional study in 2019 showed that 4 buildings partially retained the features of the previous construction period (early 1930s). For example, the block "D" was fundamentally rebuilt in the 1950s only in the part of the entrance area.

Conclusions. Modern traffic flows in the building were considered and it was determined that block "D" continues to fulfill the function of distributing traffic flows, and the best place for the elevator is the staircase in this building.

In the distribution block the entrance hall rebuilt by $\mathrm{N}$. Podgorny is a unique interior that completely preserves the artistic characteristics of the Stalin's art deco. New inclusion to this interior is not possible.

The staircase hall closest to the avenue retained the features of the early 1930s and also should preserve some authentic elements as much as possible. However, a comparative analysis with other monuments of this period showed that the design of the stairs proposed by Steinberg had variations, one of them had an elevator inside it.

In such stairwells, elevators were enclosed in a transparent sheath to show the machine's action. In the 1930s, the transparent walls of the elevator shaft were made of wire mesh, but in order to emphasize the introduction of a new non-genuine element in the staircase composition, it was proposed to assemble the elevator in a transparent glass shaft.

During ongoing repairs, the hall lost much of its long lining. The most valuable parts to keep are the staircase structure and the metal part of the railing. Therefore, during the installation of the new elevator, it is recommended to fix pointwise the new elevator frame to the old structure, and to determine the elevator location with the possibility of minimal demolition of the old stair railing sections.

\section{LITERATURE}

1. International charter for the conservation and restoration of monuments and sites (the Venice charter 1964) [Електронний ресурс] : IInd International Congress of Architects and Technicians of Historic Monuments, Venice, 1964. Adopted by ICOMOS in 1965. - Режим доступу: https://www.icomos.org/charters/venice_e.pdf/

2. Міжнародна хартія про принципи аналізу, збереження та реставрації будівель архітектурної спадщини. Прийнята 14-ю Генеральною Асамблеєю ІКОМОС, Вікторія Фолз, Зімбабве, жовтень 2003 р. // Міжнародні засади охорони нерухомої культурної спадщини. - К.: Фенікс, 2008. - С. 111-113.

3. Реставрация памятников архитектуры / С. С. Подъяпольский, Г. Б. Бессонов, Л. А. Беляев, Т. М. Постников. - М.: Стройиздат, 2000. - 288 с.

4. История ХНУРЭ [Електронний ресурс] // ХНУРЭ. Харьковский национальный университет радиоэлектроники. - Режим доступа: https://nure.ua/ru/branch/muzey-istorii-hnure/istorija-hnurje

5. Утворення харківського інженерно-будівельного інституту. - Режим доступу: http://www.logos.biz.ua/proj/hnue/019.php

6. Штейнберг Я. А. До проекту Будівельного інституту в м. Харкові // Будівництво. 1930. - № 10-11. - С. 283-288.

7. Харьков. Архитектура, памятники, новостройки / сост. А. Ю. Лейбфрейд, В. А. Реусов, А. А. Тиц. - 2-е изд., испр. и доп. - Х.: Прапор, 1987. - 151 с. 
8. Харьковские вузы 1940 года [Електронний ресурс] // Харьков: новое о знакомых местах. Статьи и страницы краеведческого альбома. - Режим доступу: https://ngeorgij.livejournal.com/29413.html

\section{РАЗВИТИЕ И СТАНОВЛЕНИЕ АРХИТЕКТУРЫ ЭЛЛИНСКОГО ТЕАТРА ОТ НАРОДНОГО ТАНЦА ДО ТЕАТРАЛЬНОГО СООРУЖЕНИЯ, VII-II ВВ. ДО Н. э.}

Василенко А. Б., док. арх., профессор, зав. кафедрой ДАС

Польщикова Н. В., канд. арх., доцент кафедры ДАС

Марценюк О. И., ассистент кафедры ДАС

Намчук А.В., ассистент кафедры ДАС

Одесская государственная академия строительства и архитектуры

Тел. (048) 732-18-01

Аннотация: Научная статья рассматривает развитие и становление типа театра Эллады от архаического периода, VII в. до н. э., к началу римского времени в Восточном Средиземноморье, II в. до н. э. В VII в. до н. э. в Элладе начала складываться традиция сельского народного праздника - Дионисий, посвященного концу сбора урожая винограда и богу плодородных сил земли, растительности, виноградарства и виноделия - Дионису. Постепенно праздник стал перемещаться в города, где превратился для горожан в зрелищное действие. Для Дионисий, ставших ежегодно традиционными, постепенно начал образовываться тип зрелищного сооружения, в котором выступали хор, актеры и находились зрители - граждане города. К началу классического периода, V-IV вв. до н. э., тип театра сформировался как стационарный, для строительства которого использовался рельеф местности. Основой архитектуры такого типа театра было размещение зрительских мест, воронкообразно полукругом спускавшихся к ровной площадке круглого плана - месту действия хора и актеров. В эпоху эллинизма, кон. IV - нач. II в. до н.э., полностью образовался тип театрального сооружения Эллады. Римляне, завоевавшие многие ее территории к сер. IV в. до н. э. (кроме Египта), получили готовый тип зрелищного сооружения, который стали развивать далее в соответствии со своей культурой.

Ключевые слова: праздник, народный танец, театр, зрелищное сооружение, сцена, тип сооружений, вместимость.

\section{РОЗВИТОК І СТАНОВЛЕННЯ АРХІТЕКТУРИ ЕЛЛІНСЬКОГО ТЕАТРУ ВІД НАРОДНОГО ТАНЦЮ ДО ТЕАТРАЛЬНОЇ СПОРУДИ, VII-II вВ. ДО Н. е.}

Василенко О. Б., док. арх., професор, зав. кафедри ДАС

Польщікова Н. В., канд. арх., доцент кафедри ДАС

Марценюк О. І., асистент кафедри ДАС

Намчук О.В., асистент кафедри ДАС

Одеська державна академія будівництва та архітектури

Тел. (048) 732-18-01

Анотація: Наукова стаття розглядає розвиток і становлення типу театру Еллади від архаїчного періоду, VII ст. до н. е., до початку римського часу в Східному Середземномор'ї, II ст. до н. е. В VII ст. до н. е. в Елладі почала складатися традиція сільського народного свята - Діонісій, присвяченого кінцю збору врожаю винограду і богу родючих сил землі, 